\title{
Expert System to Diagnose Diseases in Durian Plants using Naïve Bayes
}

\author{
Narantyo Maulana Adhi Nugraha, Reva Rahardian, Adam Nur Kridabayu, Faisal Dharma Adhinata*, \\ Nur Ghaniaviyanto Ramadhan
}

Department of Software Engineering, Faculty of Informatics, Institut Teknologi Telkom Purwokerto, Jawa Tengah, Indonesia Email: ${ }^{1} 19104048 @$ ittelkom-pwt.ac.id, ${ }^{2} 19104076 @$ ittelkom-pwt.ac.id, ${ }^{3} 19104078 @$ ittelkom-pwt.ac.id,

4,*faisal@ittelkom-pwt.ac.id, ${ }^{5}$ ghani@ittelkom-pwt.ac.id

Email Penulis Korespondensi: faisal@ittelkom-pwt.ac.id

Submitted: 20/12/2021; Accepted: 27/12/2021; Published: 31/12/2021

\begin{abstract}
Durian is a fruit that is very popular and very easy to find throughout Indonesia. Durian fruit is a thorny fruit with a very pungent smell with a distinctive taste, and for some durian fans, the distinctive taste of durian is what makes durian unique compared to other fruits. However, it is unfortunate that the production and quality of durian fruit in Indonesia is currently still low due to the limited knowledge of farmers in caring for and maintaining durian plants from pests and diseases on durian plants. So far, in detecting pests and diseases, farmers still carry out pest and disease detection manually, and of course, this is very dependent on pest and disease observers/experts. For this reason, so that later the level of production and quality of durian in Indone sia can increase, we create an expert system to diagnose a disease in durian plants to help farmers overcome problems around pests and diseases commonly occur in durian plants. This study uses the Naïve Bayes method as a determinant of durian disease. The experimental results yield an accuracy of $82 \%$, which indicates the proposed method is quite good in diagnosing durian disease.
\end{abstract}

Keywords: Disease; Durian; Expert system; Farmer; Naïve Bayes

\section{INTRODUCTION}

For most people in Indonesia, durian is one of the most popular and favourite fruits. This fruit, popular in Southeast Asia, has earned the nickname "the king of fruits" [1]. Given the popularity of durian in Indonesia, the durian plant is one of the plants with its charm in the public's eyes. Currently, durian plantations in Indonesia are growing at a reasonably rapid rate. Durian plants grow and are cultivated in almost all parts of the archipelago.

Indonesia has durian-producing areas spread over several provinces in Indonesia. However, the level of durian production in Indonesia per year only reaches one-third and one-half of durian production from Thailand and Malaysia, capable of producing durians of up to 500-700 thousand tons per year [2]. Lampung province is one of the durian-producing regions in Indonesia, which can only produce 14,620 tons of durian per year [3]. One of the factors in the decline in durian production is the presence of diseases in durian that not all farmers know. Only a few experts know.

Some of the diseases that often attack durian trees include: (Phytophthora palmivora) or often known as spot cancer (Pythium complectens) or often known as base rot, (Ganoderma philippii) or often known as base disease, (P - palmivora) or often known as seedling disease, (P. palmivora) or often known as dead tip disease, (Upasia salmonicolor) or often known as upas fungus disease, then there are leaf spots, leaf blight and fruit rot [4].

There is also stem rot and shooting death of durian, caused by the pathogen P. palmivora. The disease caused by the pathogen P. palmivora is a disease that is very feared by durian farmers because the mortality rate of durian plants due to attacks can reach up to 50\%, and of course, this will be very detrimental. For example, cases resulting from this disease attack exist in durian farms in Penang, Malaysia. Reported in this case, this disease has damaged up to $30 \%$ of durian farms [5].

Furthermore, one of the diseases that are also very dangerous for durian trees is stem rot disease, infection causes the disease from Phytophthora intertwined through the base of the stem, and after that, it will spread to the root base, and this, of course, can disrupt and damage the food transport system on the stem. , the leaves fall until the worst is the death of the infected durian tree. The process of detecting pests and diseases on durian trees by farmers is still done manually by bringing observers of pests and plant diseases to the location to make observations. It is impractical and will be very difficult for new farmers to detect pests and diseases on their durian trees because manual observations are very dependent on observers of pests and plant diseases that are limited in number [6].

Based on these problems, in this study, we took the initiative to create an expert system entitled "Expert System to Diagnose Diseases in Durian Plants using Naïve Bayes". This research is expected to assist farmers in finding solutions from the diagnosis of pests and diseases on durian trees to increase production yields.

\section{RESEARCH METHOD}

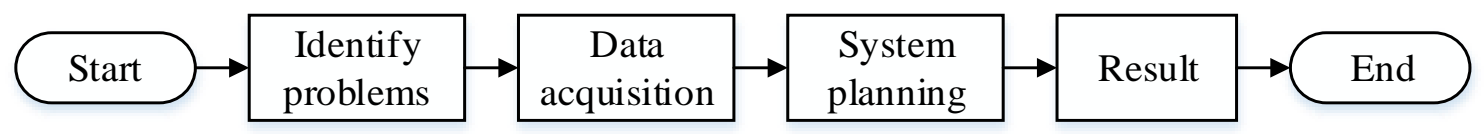

Figure 1. Research Method Flow

\subsection{Research Method Flow}


In this study, the first step we took was to identify what problems exist in the durian tree plant. After knowing the existing problems, we collected data from various sources. After the data was collected, we started to design a system using existing data to make an expert system to diagnose diseases in durian trees, which we then wrote down in the form of expert system accuracy. This accuracy indicates the success rate of our expert system.

\subsection{Expert System}

In general, an Expert system or what we are more familiar with as an Expert System, is a system created to attempt to adopt knowledge from humans into computers [7], with the aim that the computer can later solve a problem like an expert. A sound expert system is designed to solve a specific problem by imitating the performance of experts. With an expert system like this, even ordinary people can solve quite complicated problems that can only be solved by an expert [8].

\subsection{Naïve Bayes method}

Naive Bayes is a method that can be used to predict probabilities [9]. On the other hand, Bayesian classification is a statistical classification that can predict the class of a subset of probability members. In a nave Bayesian Classifier or what is known as a simple Bayesian classification, it can be assumed that the impact of an attribute value of a given class is independent of other attributes. Naïve Bayes Classifier is a classification method in which the method is rooted in the Bayes theorem [10]. The main characteristic of the Naïve Bayes Classifier is a powerful assumption (naive) and then independence from each condition/state. The following calculation steps from nave Bayes can be done:

1. Calculate the average of each class by using the equation to get the prior value of each class using equation (1).

$$
\begin{array}{ll}
P=\frac{X}{A} & \\
\text { where, } & \\
\mathrm{P} & : \text { prior value } \\
\mathrm{X} & : \text { the amount of data in each class } \\
\mathrm{A} & : \text { the amount of data in all classes }
\end{array}
$$

2. Using equation (2) to find the Likelihood value for each class.

$$
\begin{array}{ll}
L=\frac{F}{B} & \\
\text { where, } & \\
\mathrm{L} & : \text { likelihood value } \\
\mathrm{F} & : \text { number of feature data in each class } \\
\mathrm{B} & : \text { sum of all features in each class }
\end{array}
$$

3. Finding the posterior value of each existing class using equation (3).

$P(c \mid a)=P(c) x P(a \mid c)$

where,

$P(c) \quad$ : prior value in each class

$P(a \mid c) \quad$ : likelihood value

The classification results using Naive Bayes can be done by first equating the posterior values in each class. The class with the highest posterior value will be the result of the classification [11].

\subsection{Types of Durian Plant Diseases}

According to Rodame M. Napitupulu [12] in his book entitled "Unggul Durian Gardening", that durian fruit plants have several kinds of pests and diseases, including:

1. (Batocera sp, Xyleutes sp) or commonly known as stem borer, these pests attack durian plants by laying eggs on the surface of the fruit skin and then covered with a kind of net. After the larvae hatch, the larvae will enter the durian fruit by making a hole in the skin.

2. (Tirathaha sp, Dacus dorsalis) Alternatively, commonly known as the fruit borer, this disease occurs due to the invasion of Hypoperigea leprosticta. The insect attacks by laying eggs on the durian fruit it infests.

3. (Pseudococcus sp.) or commonly known as mealybugs. It is called a mealybug because the pest produces a kind of white, cottony substance that contains wax used to cover the insect's entire body. It is what causes mealybugs to look like white dust attached to plants.

4. Stem cancer, this disease is caused by an attack from the fungus Phytophthora Palmivora. Usually, this disease often occurs during the transition season.

5. Root rot, this disease is caused by Pythium complectens Braun.

6. Leaf spot, this disease is caused by an attack from the fungus Rhizoctonia solan. This disease can hit, starting at the time of the nursery process until the plants are already in the garden. This disease will quickly develop and spread when the rainfall conditions are high enough.

7. Upas Mushroom, or commonly known as pink disease. This disease is caused by the attack of the fungus Corticium salmonicolor.

8. White Root this disease is caused by an attack from the fungus Rigidoporus lignosus.

9. Mini Bee, this pest has a blackish-brown body and has wide wings with white lines. This pest will only attack plants when the bee is in the caterpillar phase, the target part of this pest is on the twigs and the young leaves. 
10. Inti Wet, this disease can be caused by heavy rains that often occur before harvest day. The heavy rain will cause water to enter the fruit that is ready to be harvested

11. Leaf blight, this disease is caused by an attack from the fusarium fungus.

\subsection{Treatment of Durian Plant Diseases}

Here are some treatments for durian plant diseases [6]:

1. (Batocera sp, Xyleutes sp) or what we often know as the stem borer. One of the prevention efforts that we can do is by maintaining proper sanitation of the durian garden. If there are stems, branches, and twigs that have been infected, we must hurry to cut and destroy the infected stems, branches, and twigs with the aim that these pests do not infect other parts of the plants that have not been infected. For rods with holes due to hoists, it should be closed as soon as possible. We can cover the hollow stems using cotton that has been given Paraffin Carbolinium Plantarum with a concentration of about two cc/litre.

2. Fruit borer, when fruit borer pests attack plants, one alternative way that we can try to overcome these pests is by using natural enemies of the fruit borer by using Venturia sp, Tachinidae, and Apanteles tirathabae flies. Then to prevent pest transmission from spreading to other durian fruits that are still not attacked, the efforts we can make are to collect the fruit that has been attacked and then burns it so that the pests on the affected fruit can die. As for plant healing, we can use Deltamethrin pesticides, such as Decis 2.5 EC or Beta Cyfluthrin (Buldk 25 $\mathrm{EC})$.

3. Measles, one of the efforts to control the invasion of mealybugs that we can try is by maintaining garden sanitation to avoid weeds and other host plants, such as soursop, cocoa, coffee, and oranges. Not only that but efforts to prevent the emergence of mealybug attacks can also be made by avoiding the presence of fruit in the dompolan by thinning the fruit. Meanwhile, to eliminate it, one way that we can use and apply is to spray the trees using an insecticide containing the active ingredient Lambda Cyhalothrin or Deltamethrin at a dosage following the existing usage recommendations.

4. Stem cancer, one of the ways that we can try to do as an effort to prevent the invasion of this disease is to maintain and maintain good garden sanitation, provide distance between plants, suppress weed growth, use resistant rootstock, use disease-free seeds, and Regular pruning of branches.

5. Avoiding the attack of root rot disease can be tried by improving drainage and using a base stem that is resistant to disease. Plants that have been infected must be dismantled and destroyed. While the control can use fungicides with active ingredients Metalaxyl, Phosphonate and Fosetyl Aluminum with active ingredients Mankozeb, such as Dithane M45 with doses following the recommended usage on the packaging.

6. Leaf spot disease Avoidance of leaf spot disease attacks can be tried by thinning the spacing. Meanwhile, on plants that have been infected, immediately prune the branches infected with the disease and continue to spray a fungicide containing active copper with a dose according to the recommendations tucked in the package.

7. Upas fungal disease can be prevented by using the perfect spacing of $10 \mathrm{~m} \times 10 \mathrm{~m}$. The existing avoidance activities are by regularly clearing the land, pruning and spraying fungicides. The fungicide used should contain the active ingredient Mankozeb, similar to Dithane M45, regularly with the dosage following the recommended usage on the package.

8. White root disease, prevention efforts that we can try to overcome the invasion of white root disease by using healthy seeds and avoiding disease, repairing and maintaining drainage channels, and also maintaining the land so that it is not wet and free of weeds. To avoid transmission to healthy plants, diseased host plants should be disposed of immediately. Not only that, for chemical avoidance, we can also use fungicides.

9. To prevent mini bees, it can be controlled by using larvicides, such as Hostathion 40 EC (Triazofos $420 \mathrm{~g} /$ liter), and insecticides, such as Supracide $40 \mathrm{EC}$ at a dose of $420 \mathrm{~g} / \mathrm{liter}$ and Temik 106 (Aldi Karl 10\%).

10. It can be done to prevent a wet core by removing the water that has soaked the plants to not seep into the stems and durian fruit.

11. Leaf blight prevention can be done by pruning twigs and branches that have died and have been infected with leaf blight disease, with the aim of not spreading to other branches and branches of plants that are still not infected with the disease. When pruning branches that have been infected, also do pruning on parts of the so dense branches so that sunlight can reach all parts of the plant.

\subsection{System evaluation}

In this study, experiments will be carried out to test how accurate the expert system is made. We made this system based on a website. The system input starts from the symptoms of durian disease. Through several experiments, we evaluated the system output results with the actual disease results.

\section{RESULT AND DISCUSSION}

Table 1 describes the names of the diseases and their symptoms that will be used in the expert system in diagnosing this disease. 
Table 1. Names of diseases and symptoms of durian plants

\begin{tabular}{|c|c|}
\hline Disease Name & Symptom \\
\hline Stem Borer & $\begin{array}{l}\text { a. There is a hole in the stem } \\
\text { b. Plants wither } \\
\text { c. Leaves fall } \\
\text { d. Leaves dry }\end{array}$ \\
\hline Fruit Borer & $\begin{array}{l}\text { a. caterpillar rotten fruit } \\
\text { b. There is a hole in the skin of the fruit } \\
\text { c. There are eggs on the skin of the fruit }\end{array}$ \\
\hline White Flea & $\begin{array}{l}\text { a. Leaves withered } \\
\text { b. Leaves become curly } \\
\text { c. The skin of the fruit becomes white } \\
\text { d. There are many ants on the fruit }\end{array}$ \\
\hline Stem Cancer & $\begin{array}{l}\text { a. The discharge is a kind of red colored mucus on } \\
\text { the skin at the base of the stem } \\
\text { b. Stems on plants become rotten } \\
\text { c. Plants wither }\end{array}$ \\
\hline Rotten Root & $\begin{array}{l}\text { a. Plants wither } \\
\text { b. Leaves fall } \\
\text { c. The color of the skin on the plant changes to dark } \\
\text { brown } \\
\text { d. Many plant branch tips die }\end{array}$ \\
\hline Leaf Spots & $\begin{array}{l}\text { a. Leaves fall } \\
\text { b. Leaves become hollow } \\
\text { c. Large dry spots appear on the leaves }\end{array}$ \\
\hline Peeled Mushroom & $\begin{array}{l}\text { a. The stems die. } \\
\text { b. There is a kind of yellow liquid covered with a } \\
\text { net. }\end{array}$ \\
\hline White Root & $\begin{array}{l}\text { a. Leaf color turns yellow } \\
\text { b. Leaves become shriveled } \\
\text { c. Leaves fall }\end{array}$ \\
\hline Mini Bee & $\begin{array}{l}\text { a. There are bees and their nests attached to young } \\
\text { leaves } \\
\text { b. Leaves become hollow } \\
\text { c. Leaves turn yellow }\end{array}$ \\
\hline Wet Core & $\begin{array}{l}\text { a. There is a puddle of water around the tree } \\
\text { b. Fruit looks wet and becomes mushy } \\
\text { c. Stems look wet and become mushy }\end{array}$ \\
\hline Leaf Blight & $\begin{array}{l}\text { a. The presence of spots on the leaves that have a } \\
\text { blackish brown color which will then develop } \\
\text { into dryness. } \\
\text { b. Twigs and branches on plants become dry and } \\
\text { die. }\end{array}$ \\
\hline
\end{tabular}

\subsection{Accuracy Testing}

In this study, several experiments were carried out by including the symptoms of the disease. Then we evaluate the system diagnostics with the actual disease (expert diagnosis). The test results are shown in Table 2.

Table 2. Test results of durian disease expert system

\begin{tabular}{|c|c|c|c|c|}
\hline No & Symptom & $\begin{array}{c}\text { Diagnosis } \\
\text { System }\end{array}$ & $\begin{array}{c}\text { Diagnosis } \\
\text { Expert }\end{array}$ & $\begin{array}{c}\text { Results } \\
\text { Test }\end{array}$ \\
\hline 1 & $\begin{array}{ll}\text { - } & \text { There is a hole in the stem } \\
\text { - } & \text { Plants wither } \\
\text { - } & \text { Leaves fall } \\
\text { - } & \text { Leaves dry }\end{array}$ & Stem Borer & Stem Borer & after \\
\hline 2 & $\begin{array}{l}\text { - } \quad \text { caterpillar rotten fruit } \\
\text { - There is a hole in the skin of the fruit } \\
\text { - The eggs on the skin of the fruit }\end{array}$ & Fruit Borer & Fruit Borer & $\begin{array}{c}\text { In } \\
\text { accordance }\end{array}$ \\
\hline 3 & $\begin{array}{l}\text { - Leaves withered } \\
\text { - } \quad \text { The skin of the fruit becomes white }\end{array}$ & White Flea & White Flea & $\begin{array}{c}\text { In } \\
\text { accordance }\end{array}$ \\
\hline
\end{tabular}




\begin{tabular}{|c|c|c|c|c|}
\hline No & Symptom & $\begin{array}{l}\text { Diagnosis } \\
\text { System }\end{array}$ & $\begin{array}{c}\text { Diagnosis } \\
\text { Expert }\end{array}$ & $\begin{array}{c}\text { Results } \\
\text { Test }\end{array}$ \\
\hline 4 & $\begin{array}{l}\text { There are many ants on the fruit } \\
\text { The discharge of a kind of red-patterned mucus on the } \\
\text { skin at the base of the stem } \\
\text { Stems on plants become rotten }\end{array}$ & $\begin{array}{l}\text { Not } \\
\text { detected }\end{array}$ & Stem Cancer & $\begin{array}{l}\text { It is not in } \\
\text { accordance } \\
\text { with }\end{array}$ \\
\hline 5 & $\begin{array}{l}\text { Plants wither } \\
\text { Plants wither } \\
\text { The color of the skin on the plant changes to dark } \\
\text { brown }\end{array}$ & Rotten Root & Rotten Root & $\begin{array}{l}\text { In } \\
\text { accordance }\end{array}$ \\
\hline 6 & $\begin{array}{l}\text { - Leaves fall } \\
\text { - Laves become hollow } \\
\text { Large dry spots appear on the leaves }\end{array}$ & Leaf Spots & Leaf Spots & $\begin{array}{l}\text { In } \\
\text { accordance }\end{array}$ \\
\hline 7 & $\begin{array}{l}\text { - The stems die. } \\
\text { - There is a kind of yellow liquid covered with a net. }\end{array}$ & $\begin{array}{l}\text { Peeled } \\
\text { Mushroom }\end{array}$ & $\begin{array}{l}\text { Peeled } \\
\text { Mushroom }\end{array}$ & $\begin{array}{l}\text { In } \\
\text { accordance }\end{array}$ \\
\hline 8 & $\begin{array}{ll}\text { - } & \text { Leaf color turns yellow } \\
\text { - } & \text { Leaves become shriveled } \\
\end{array}$ & White Root & White Root & $\begin{array}{l}\text { In } \\
\text { accordance }\end{array}$ \\
\hline 9 & $\begin{array}{l}\text { - } \quad \text { There are bees and their nests attached to young leaves } \\
\text { - Leaves become hollow } \\
\text { Leaves turn yellow }\end{array}$ & Mini bee & Mini bee & $\begin{array}{l}\text { In } \\
\text { accordance }\end{array}$ \\
\hline 10 & $\begin{array}{l}\text { - } \quad \text { There is a puddle of water around the tree } \\
\text { - } \quad \text { Stuit looks wet and becomes mushy } \\
\text { look wet and become mushy }\end{array}$ & Wet Core & Wet Core & $\begin{array}{l}\text { In } \\
\text { accordance }\end{array}$ \\
\hline 11 & $\begin{array}{l}\text { - The presence of spots on the leaves that have a blackish } \\
\text { brown color which will then develop into dryness. } \\
\text { - Twigs and branches on plants become dry and die. }\end{array}$ & $\begin{array}{l}\text { Not } \\
\text { detected }\end{array}$ & Leaf Blight & $\begin{array}{l}\text { It is not in } \\
\text { accordance } \\
\text { with }\end{array}$ \\
\hline
\end{tabular}

Based on Table 2, the accuracy of the durian disease expert system can be calculated as follows:

$$
\begin{aligned}
\text { Accuracy value } & =\frac{\text { number of accurate experiment }}{\text { sum of all experiment }} \times 100 \% \\
& =\frac{9}{11} \times 100 \% \\
& =82 \%
\end{aligned}
$$

In the accuracy test carried out on the expert system to diagnose diseases in durian plants, it resulted in an accuracy rate of $82 \%$. And from the results of the test value of $82 \%$, an error value of $18 \%$ was obtained because there were 2 symptoms of the disease that were not detected by the system. namely stem cancer and leaf blight with detail error stem cancer occurring in the 4th test and leaf blight occurring in the $11^{\text {th }}$ test.

\subsection{Durian Disease Diagnosis Expert System Display}

\section{Home View}

When the user enters the web it will display the main page as shown in Figure 2. There is an explanation regarding the durian plant. Then on the left sidebar, there is a disease diagnosis menu, a list of diseases, and about. The disease diagnosis menu is used to detect disease based on symptom input. Then the disease list menu contains diseases in durian plants.

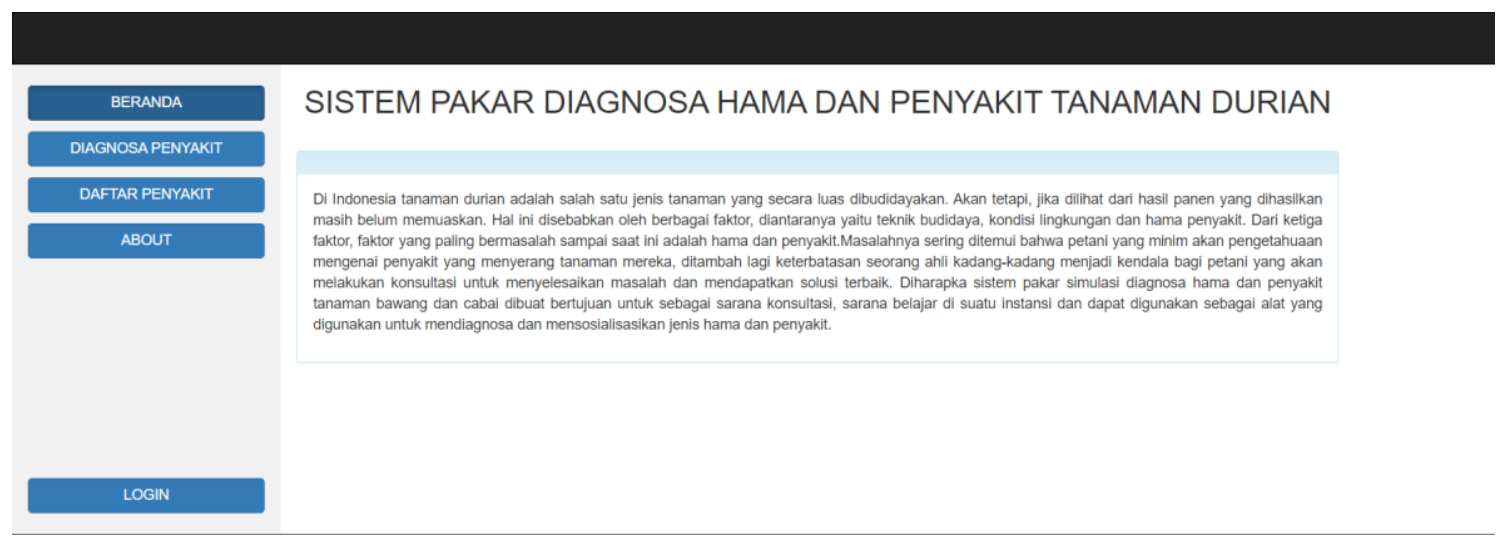

Figure 2. Display of the homepage on the expert system for diagnosing diseases in durian plants 
Building of Informatics, Technology and Science (BITS)

Volume 3, No 3, Desember 2021 Page: 346-352

ISSN 2684-8910 (media cetak)

ISSN 2685-3310 (media online)

DOI 10.47065/bits.v3i3.1077

\section{Disease Symptoms}

On this page, the user can diagnose the disease by selecting the symptoms that exist in the durian plant as shown in Figure 3. There is a choice of disease symptoms in durian, starting from the roots, stems, and leaves. User can select more than one symptom in this menu.

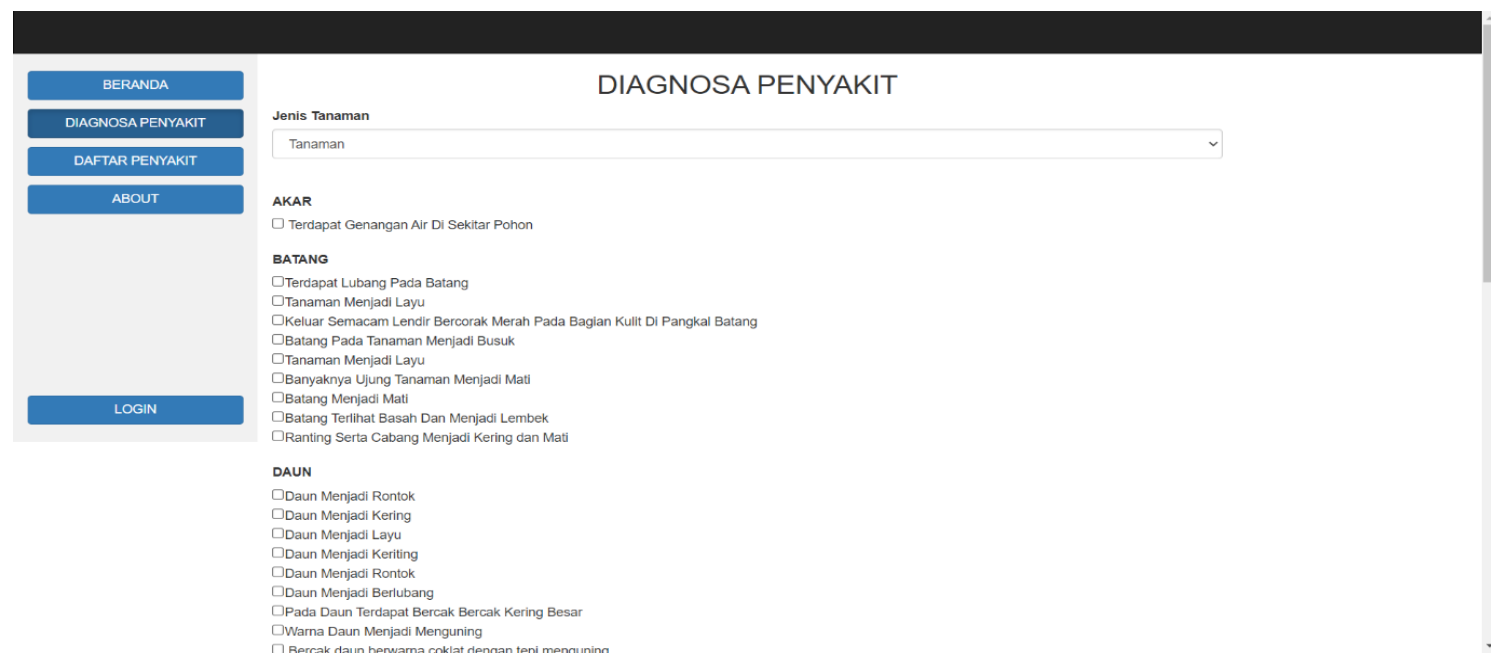

Figure 3. Display of disease symptoms in an expert system for diagnosing diseases in durian plants

\section{Diagnostic Results}

This page displays the results of disease diagnosis in durian plants as shown in Figure 4. Users can diagnose diseases through the disease diagnosis menu. In this menu, you can also view the details of the disease by pressing the button in the detail column.

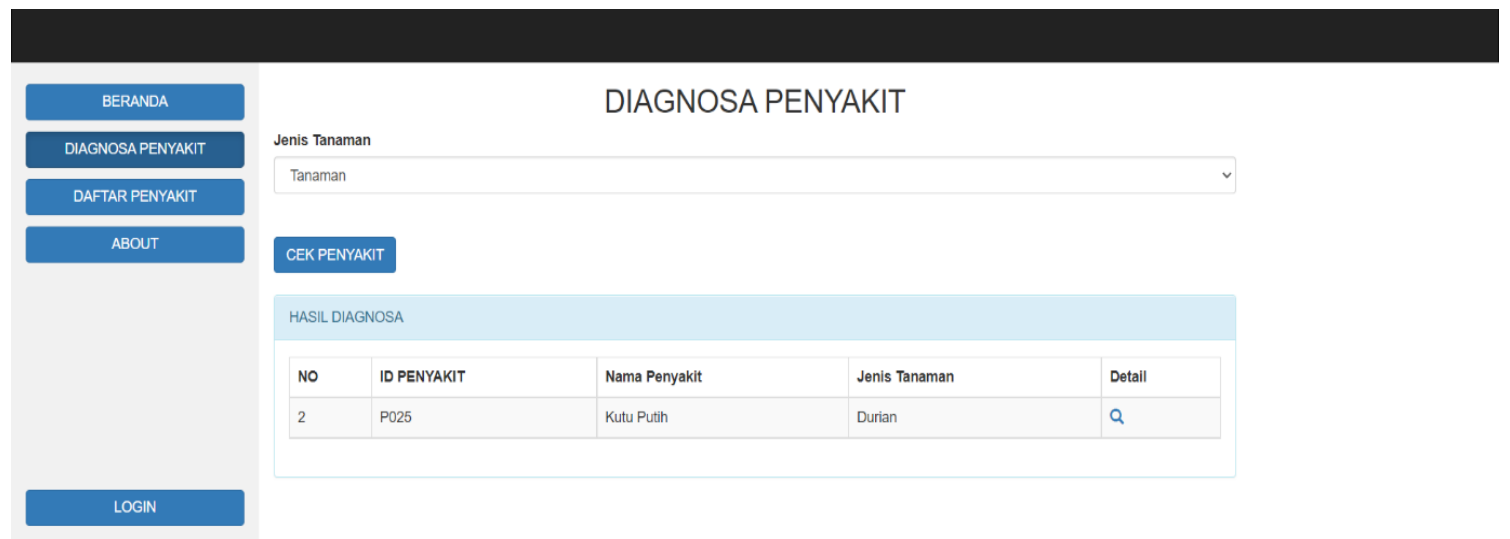

Figure 4. Display of disease diagnosis results on durian plants

\section{Disease Details}

Figure 5 contains a detailed display of the diagnostic results of durian plants, starting from the name of the disease, technical culture, mechanical handling, and also chemical handling. Through this menu, farmers can make efforts to treat durian plants.

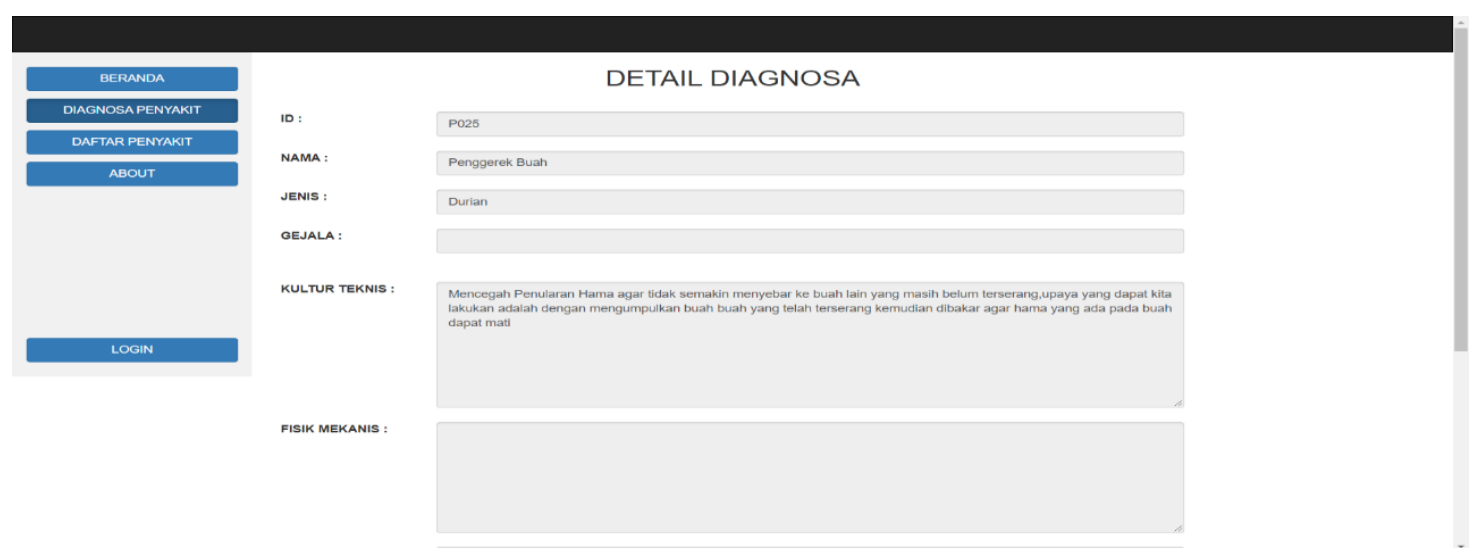

Figure 5. Display of disease details in an expert system for diagnosing diseases in durian plants 


\section{CONCLUSION}

From the results of the research that we have made on the durian disease diagnosis system using the Naive Bayes method, this system is proven to be able to identify diseases in durian plants which is done by entering the symptoms caused by the durian plant and will later be calculated using the Naive Bayes method and produce the name of the disease that attacked him. The process of determining the identification results, this system will first equalize the posterior values that exist in each disease. Then the posterior result with the highest value will be the result of the classification in the durian plant disease diagnosis system. The experimental results show that the expert system created is able to produce an accuracy of $82 \%$. Through this research, it is hoped that it can help farmers as an early detection of durian disease so that early and appropriate treatment and treatment can be carried out. This research still needs to improve its accuracy, so that future research can combine it with other methods, for example using the certainty factor.

\section{REFERENCES}

[1] S. Aldy and P. Suryadarma, "Peningkatan Nilai Tambah Durian Afkir melalui Produksi Dodol Durian di Kuala Selangor Malaysia Increasing Rejected Durian Added Value through Durian Dodol Production in Kuala Selangor Malaysia," Jurnal Pusat Inovasi Masyarakat, vol. 1, no. November, pp. 92-98, 2019.

[2] P. J. Santoso, "Indonesia Berpotensi Produksi Durian Sepanjang Tahun (Indonesia's Potential for Durian Production Yearround)," SinarTani: Agroinovasi, vol. 19, no. 3487, pp. 10-16, 2012.

[3] B. P. Statistik, "Produksi Tanaman Buah-buahan 2020," www.bps.go.id, 2020. https://www.bps.go.id/indicator/55/62/1/produksi-tanaman-buah-buahan.html (accessed Nov. 13, 2021).

[4] A. Handoko, A. L. Abadi., and L. Q. Aini, "Karakterisasi Penyakit Penting Pada Pembibitan Tanaman Durian di Desa Plangkrongan, Kabupaten Magetan dan Pengendalian dengan Bakteri Antagonis Secara In Vitro," Jurnal Hama dan Penyakit Tumbuhan, vol. 2, no. 2, pp. 15-22, 2014.

[5] H. Triwidodo, S. Wiyono, and P. B. Ayuwati, "Teknik Pembibitan dan Organisme Pengganggu Bibit Durian Menoreh Kuning di Kecamatan Kalibawang, Kulon Progo,” Agrovigor: Jurnal Agroekoteknologi, vol. 13, no. 1, pp. 43-50, 2020, doi: 10.21107/agrovigor.v13i1.6061.

[6] "Seminar Nasional Program dan Strategi Pengembangan Buah Nusantara,” no. Bps 2001, pp. 176-189, 2005.

[7] H. Listiyono, "Merancang dan Membuat Sistem Pakar," Jurnal Teknologi Informasi DINAMIK, vol. XIII, no. 2, pp. 115$124,2008$.

[8] Y. A. Fitrianingtyas and C. Rahmad, "Sistem pakar deteksi hama dan penyakit pada tanaman cabai dengan metode naïve bayes," Jurnal Prosiding Seminar Informatika Aplikatif Polinema, vol. 2015, no. 1, pp. 68-72, 2015.

[9] S. Syarli and A. Muin, "Metode Naive Bayes Untuk Prediksi Kelulusan (Studi Kasus: Data Mahasiswa Baru Perguruan Tinggi)," Jurnal Ilmiah Ilmu Komputer, vol. 2, no. 1, pp. 22-26, 2016.

[10] T. Rosandy, "PERBANDINGAN METODE NAIVE BAYES CLASSIFIER DENGAN METODE DECISION TREE (C4.5) UNTUK MENGANALISA KELANCARAN PEMBIAYAAN (Study Kasus : KSPPS / BMT AL-FADHILA),” Jurnal Teknologi Informasi Magister Darmajaya, vol. 2, no. 01, pp. 52-62, 2016.

[11] E. Sudaryanto and A. Suryanto, "Sistem Pakar Diagnosa Hama Dan Penyakit Tanaman Durian Dengan Metode Naive Bayes," Teodolita, vol. 21, no. 1, pp. 59-64, 2020.

[12] R. M. Napitupulu, Bertanam Durian Unggul. PT Niaga Swadaya, 2010.

[13] A. Furqon and N. I. Fadlilah, "Sistem Pakar Untuk Mendiagnosa Hama Dan Penyakit Pada Pohon Durian," Konferensi Nasional Ilmu Sosial \& Teknologi (KNiST), pp. 105-109, 2016. 